\title{
Thermus islandicus sp. nov., a mixotrophic sulfur-oxidizing bacterium isolated from the Torfajokull geothermal area
}

Correspondence

Solveig K. Petursdottir

solveigp@matis.is

\author{
Snaedis $H$. Bjornsdottir, ${ }^{1,2}$ Solveig K. Petursdottir, ${ }^{1}$ \\ Gudmundur O. Hreggvidsson, ${ }^{1,2}$ Sigurlaug Skirnisdottir, ${ }^{1}$ \\ Sigridur Hjorleifsdottir, ${ }^{1}$ Johann Arnfinnsson ${ }^{3}$ and Jakob K. Kristjansson ${ }^{4}$ \\ ${ }^{1}$ Matis-Prokaria, Gylfaflot 5, IS-112 Reykjavik, Iceland \\ ${ }^{2}$ Institute of Biology, University of Iceland, Sturlugata 7, IS-101, Reykjavik, Iceland \\ ${ }^{3}$ Division of Anatomy, University of Iceland, Vatnsmyrarvegur 16, IS-101, Reykjavik, Iceland \\ ${ }^{4}$ Arkea Technology Park, Reykir, PO Box 200, IS-810, Hveragerdi, Iceland
}

\begin{abstract}
Strains PRI 2268 and PRI $3838^{\top}$ were isolated from two separate hot springs in the Torfajokull geothermal area of South Iceland. The cells were non-motile rods, approximately $0.3 \mu \mathrm{m}$ in width and 1.5-2.5 $\mu \mathrm{m}$ in length. Electron microscopy revealed a Gram-negative cell-wall structure. The strains grew at $45-79{ }^{\circ} \mathrm{C}$ (optimum, $65{ }^{\circ} \mathrm{C}$ ) and $\mathrm{pH}$ 5.5-10.5 (optimum, pH 6.0-7.0). 16S rRNA gene sequence analysis indicated that they formed a separate branch within the genus Thermus with 'Thermus kawarayensis' KW11 as their closest cultured relative (96.5\% similarity). The gene sequence similarities of both new isolates to Thermus aquaticus $\mathrm{YT}-1^{\top}$ and Thermus igniterrae RF- $4^{\top}$ were $96.1 \%$ and $95.5 \%$, respectively. DNA-DNA relatedness between strain PRI $3838^{\top}$ and ' $T$. kawarayensis' was $46.1 \%$. The DNA G $+C$ content of strain PRI $3838^{\top}$ was $69.0 \mathrm{~mol} \%$. The predominant menaquinones, pigmentation, fatty acid profiles and phospholipid profiles of the novel strains were similar to those of other members of the genus Thermus. However, the new strains could be differentiated from the type strains of all other species of the genus Thermus by their lack of catalase activity and their utilization of only a few carbon sources. Furthermore, the novel strains exhibited mixotrophic growth with sulfur oxidation. On the basis of 16S rRNA gene sequence comparisons, DNA-DNA hybridization and physiological and biochemical characteristics, the new isolates represent a novel species. Since the species appears to be ubiquitous in Icelandic hot springs, the name Thermus islandicus sp. nov. is proposed. The type strain is PRI $3838^{\top}\left(=\right.$ DSM $21543^{\top}=$ ATCC BAA $\left.-1677^{\top}\right)$.
\end{abstract}

Bacteria of the genus Thermus have been prominent in the history of thermophile research since the discovery of Thermus aquaticus by Brock \& Freeze in 1969. Since then, several additional Thermus species have been recognized. As a group, strains of the genus Thermus are both biochemically and metabolically quite homogeneous. Most strains are yellow-pigmented, non-sporulating rods that grow heterotrophically on various carbon sources ( $\mathrm{da}$ Costa et al., 2006). Optimal and maximal temperatures for

Abbreviation: ICP-MS, inductively coupled plasma mass spectrometry.

The GenBank/EMBL/DDBJ accession numbers for the $16 \mathrm{~S}$ rRNA gene sequences for strains PRI 2268 and PRI $3838^{\top}$ are EU753248 and EU753247, respectively.

Scanning and transmission electron micrographs of cells of the novel strains and a graph showing the effect of temperature on the growth of strains PRI 2268 and PRI $3838^{\top}$ are available as supplementary figures with the online version of this paper. growth are usually about $65-70{ }^{\circ} \mathrm{C}$ and below $80{ }^{\circ} \mathrm{C}$, respectively, and optimal $\mathrm{pH}$ for growth is around neutrality. Most Thermus strains have been described as obligate aerobes but some are known to use nitrate, ferric ion, elemental sulfur or arsenate as terminal electron acceptors (Kieft et al., 1999; Gihring \& Banfield, 2001; Skirnisdottir et al., 2001). Mixotrophic growth with the oxidation of sulfur compounds has been reported as a common trait in members of the genus Thermus (Hreggvidsson et al., 2006).

Species of the genus Thermus have been isolated from natural and artificial thermal environments around the world but exhibit different patterns of distribution. Thermus aquaticus and Thermus filiformis have so far only been encountered in the USA and New Zealand, respectively (Brock \& Freeze, 1969; Hudson et al., 1987). Thermus brockianus, Thermus oshimai and Thermus scotoductus 
show global distributions (Kristjansson et al., 1994; Williams et al., 1995, 1996), while Thermus igniterrae and Thermus antranikianii have only been isolated from hot springs in Iceland (Chung et al., 2000). Thermus thermophilus has been isolated from marine and coastal hot springs all over the world (Williams et al., 1995). T. thermophilus was the only Thermus species isolated from Japanese hot springs until recently, when the discovery of 'Thermus kawarayensis' was reported (Kurosawa et al., 2005). During an environmental assessment of the Torfajokull geothermal area commissioned by the National Energy Authority of Iceland, we encountered a hot spring, HS-605, harbouring $16 \mathrm{~S}$ rRNA gene sequences showing $96 \%$ similarity to ' $T$. kawarayensis' (unpublished results). Nearly identical sequences had previously been identified in two hot springs in south-western Iceland (Skirnisdottir et al., 2000; Hjorleifsdottir et al., 2001; Hobel et al., 2004). The aim of this work was to isolate and describe this unknown species of the genus Thermus.

Samples were collected from hot spring HS-605, which is located $603 \mathrm{~m}$ above sea level in the Torfajokull geothermal area in southern Iceland. The temperature was $74{ }^{\circ} \mathrm{C}$ at the inlet of the opening and $60{ }^{\circ} \mathrm{C}$ at the borders. The $\mathrm{pH}$ was around 6.0 and the conductivity was $234 \mu \mathrm{S} \mathrm{cm}^{-1}$. The concentrations of chloride, magnesium and sulfur were estimated as $0.6 \mathrm{mg} \mathrm{l}^{-1}, 2 \mathrm{mg} \mathrm{l}^{-1}$ and $10 \mathrm{mg} \mathrm{l}^{-1}$, respectively, using inductively coupled plasma mass spectrometry (ICP-MS). The concentration of hydrogen sulfide was determined to be $1.3 \mathrm{mg} \mathrm{l}^{-1}$ using the methylene blue method (Eaton et al., 2005). The hot spring was characterized by a conspicuous grey microbial mat that was at approximately $66-74{ }^{\circ} \mathrm{C}$ when sampled. Biomass was inoculated into R2A liquid medium (Becton Dickinson) and incubated for $24 \mathrm{~h}$ at $65{ }^{\circ} \mathrm{C}$ without shaking. Turbid cultures were streaked on agar plates containing $\mathrm{R} 2 \mathrm{~A}$, which were then incubated at $65^{\circ} \mathrm{C}$ for up to 7 days. Different colony types appeared and were picked at random with an emphasis on yellow-pigmented strains. Selected strains were purified by streaking on to the same medium. For phylogenetic characterization, DNA was isolated from cultured strains using Dynabeads DNA Direct (Invitrogen) and partial 16S rRNA gene sequences were determined as described below. Strain PRI $3838^{\mathrm{T}}$, which showed $99 \%$ gene sequence similarity to the previously detected clone sequence SRI-248 (Skirnisdottir et al., 2000), was chosen for phenotypic characterization.

During this work, we also examined yellow-pigmented strains that had been deposited uncharacterized in the Matis-Prokaria strain collection. This resulted in the identification of strain PRI 2268, which also exhibited $99 \%$ sequence similarity to the clone sequence SRI-248. This strain was isolated from a hot spring at $65-70{ }^{\circ} \mathrm{C}$ and pH 5.5 in Hrafntinnusker in the Torfajokull area. It was isolated on an R2A plate at $65{ }^{\circ} \mathrm{C}$. The reference strains used in this study, 'T. kawarayensis' (DSM 16200), $T$. aquaticus (DSM $625^{\mathrm{T}}$ ) and T. igniterrae (DSM $12459^{\mathrm{T}}$ ) were obtained from the Deutsche Sammlung von Microorganismen und Zellkulturen (DSMZ).

Isolates PRI 2268 and PRI $3838^{\mathrm{T}}$ stained Gram-negative. They produced irregular, umbonate and undulate colonies of $1-1.5 \mathrm{~mm}$ after incubation at $65{ }^{\circ} \mathrm{C}$ on medium 166 (Hjorleifsdottir et al., 2001) for 4 days. Both strains produced yellow pigments in contrast to the colourless 'T. kawarayensis' and the absorbance spectra of acetone extracts showed a peak at $450 \mathrm{~nm}$. Both novel strains exhibited oxidase activities but were catalase-negative and did not reduce nitrate, in contrast to ' $T$. kawarayensis' (Table 1). The sensitivity of strains PRI 2268 and PRI $3838^{\mathrm{T}}$ and the reference strains to antibiotics was examined. Plates containing medium 166 and standard $(6 \mathrm{~mm})$ antibiotic discs (Oxoid) were incubated at $65^{\circ} \mathrm{C}$. The inhibition zone was measured and the strains scored as sensitive to the antibiotic if the zone was $>20 \mathrm{~mm}$ in diameter (Kristjansson et al., 1994). All strains tested as sensitive to ampicillin $(10 \mu \mathrm{g})$, gentamicin $(10 \mu \mathrm{g})$, novobiocin $(30 \mu \mathrm{g})$, kanamycin $(30 \mu \mathrm{g})$, penicillin $\mathrm{G}(10 \mathrm{U})$ and streptomycin $(10 \mu \mathrm{g})$. They were resistant to nalidixic acid $(30 \mu \mathrm{g})$, polymyxin B (300 U) and rifampicin $(2 \mu \mathrm{g})$. Cells of the novel strains were non-motile and a capsule was not

Table 1. Characteristics that distinguish the new Thermus isolates from their closest relatives

Strains: 1, PRI 2268; 2, PRI $3838^{\mathrm{T}}$; 3, 'T. kawarayensis' KW11; 4, T. aquaticus DSM $625^{\mathrm{T}} ; 5$, T. igniterrae DSM $12459^{\mathrm{T}}$. The values for the DNA G $+\mathrm{C}$ content of $T$. aquaticus and T. igniterrae were obtained from da Costa et al. (2001) and Chung et al. (2000), respectively. Other data are from this study. +, Positive; -, negative; w, weak growth.

\begin{tabular}{|c|c|c|c|c|c|}
\hline Characteristic & 1 & 2 & 3 & 4 & 5 \\
\hline Pigmentation & Yellow & Yellow & - & Yellow & Yellow \\
\hline Catalase & - & - & - & + & + \\
\hline Nitrate reduction & - & - & + & - & + \\
\hline Thiosulfate oxidation & + & + & + & - & + \\
\hline Growth at $75{ }^{\circ} \mathrm{C}$ & + & + & - & + & + \\
\hline $\begin{array}{l}\text { DNA G + C content } \\
(\mathrm{mol} \%)\end{array}$ & ND & 69.0 & 68.0 & 64 & 70.3 \\
\hline \multicolumn{6}{|l|}{ Utilization of: } \\
\hline D-Arabinose & $\mathrm{W}$ & - & $\mathrm{W}$ & - & + \\
\hline L-Arginine & - & - & - & + & + \\
\hline D-Glucose & - & - & + & - & + \\
\hline L-Glutamine & + & - & - & + & + \\
\hline Glycerol & + & + & - & + & + \\
\hline myo-Inositol & + & $\mathrm{W}$ & - & + & + \\
\hline D-Mannose & - & - & $\mathrm{W}$ & + & + \\
\hline L-Rhamnose & - & - & - & + & + \\
\hline Ribitol & + & - & - & + & + \\
\hline L-Serine & - & - & - & + & - \\
\hline Starch & + & + & - & - & + \\
\hline Sucrose & - & - & - & - & + \\
\hline Trehalose & - & - & - & + & + \\
\hline
\end{tabular}


detected by crystal violet and copper sulfate or by India ink staining. Scanning electron micrographs of strain PRI $3838^{\mathrm{T}}$ showed straight rod-shaped cells, approximately $0.3 \mu \mathrm{m}$ in diameter and $1.5-2.5 \mu \mathrm{m}$ in length (see Supplementary Fig. S1, available in IJSEM Online). Transmission electron micrographs showed a thick envelope and a typical Gram-negative cell-wall profile (see Supplementary Figs S2 and S3).

Strains PRI 2268 and PRI $3838^{\mathrm{T}}$ and the reference strains were routinely grown at $65{ }^{\circ} \mathrm{C}$ in medium 166 (Hjorleifsdottir et al., 2001). The new isolates were aerobic and did not grow anaerobically with nitrate. The $\mathrm{pH}$ ranges for growth were examined at $65{ }^{\circ} \mathrm{C}$ in medium 166 buffered with $30 \mathrm{mM}$ acetate to $\mathrm{pH} 4.0-5.5,30 \mathrm{mM}$ MES to $\mathrm{pH} 6.0,30 \mathrm{mM}$ phosphate to $\mathrm{pH} 6.5-8.0,30 \mathrm{mM}$ Tricine to $\mathrm{pH} 9.0$ and by $30 \mathrm{mM}$ CAPS to $\mathrm{pH} 10.0-11.0$. Strains PRI 2268 and PRI $3838^{\mathrm{T}}$ grew optimally at pH 6.07.0 and $\mathrm{pH} 6.5-7.0$, respectively. The maximum and minimum $\mathrm{pH}$ values for growth were $\mathrm{pH} 5.5$ and $\mathrm{pH} 10.5$ for both strains. Their growth temperature ranges were examined by measuring the turbidity $\left(\mathrm{OD}_{600}\right)$ of liquid cultures. Both strains PRI 2268 and PRI $3838^{\mathrm{T}}$ grew optimally at about $65{ }^{\circ} \mathrm{C}$ and their maximum specific growth rates $(\mu)$ were determined as $0.37 \mathrm{~h}^{-1}$ and $0.29 \mathrm{~h}^{-1}$, respectively (see Supplementary Fig. S4, available in IJSEM Online). The minimum and maximum growth temperatures were about $44{ }^{\circ} \mathrm{C}$ and $79{ }^{\circ} \mathrm{C}$, respectively, for both strains. Salt tolerance tests were performed on plates with medium 166 at $65{ }^{\circ} \mathrm{C}$ and in liquid cultures and neither novel strain grew in the presence of $1 \%(\mathrm{w} / \mathrm{v})$ $\mathrm{NaCl}$. Growth on 27 different single and complex carbon sources was tested on agar plates and compared with that of 'T. kawarayensis' DSM 16200, T. aquaticus DSM $625^{\mathrm{T}}$ and T. igniterrae DSM $12459^{\mathrm{T}}$. Modified minimal medium 162 (Degryse et al., 1978) containing EGTA instead of Titriplex I was used. It also contained $0.05 \% \mathrm{NH}_{4} \mathrm{Cl}$ and $0.4 \%$ vitamin solution (Degryse et al., 1978) and was prepared either with or without $0.2 \%$ yeast extract. Carbon sources were added in concentrations of $0.2 \%$ for L-amino acids and $0.4 \%$ for other substrates. Plates were scored as positive if growth was clearly visible after 7 days. A negative control without an added organic compound was also included. Strains PRI 2268 and PRI $3838^{\mathrm{T}}$ assimilated very few carbon sources when compared with the reference strains. However, by lowering the growth temperature to $60{ }^{\circ} \mathrm{C}$, several more carbon sources were utilized and both strains grew well on pyruvate, starch and glycerol, when supplemented with yeast extract. Strain PRI 2268 also grew well on L-glutamine, D-arabinose and ribitol (Table 1). Both novel strains showed some growth on cellobiose, lactose and myo-inositol. They also grew on minimal medium supplemented with yeast extract and thiosulfate $(16 \mathrm{mM})$, both on plates and in liquid medium. Furthermore, when thiosulfate was added to medium 166 , the maximum growth rate increased, but only at high aeration. This indicated mixotrophic growth and energy harnessing oxidation of thiosulfate. This was confirmed by the production of sulfate from thiosulfate in the presence of yeast extract as determined by using $\mathrm{BaCl}_{2}$ as described by Tabatabai (1974). Strains PRI 2268 and PRI $3838^{\mathrm{T}}$ produced 4.3 and $4.5 \mathrm{mM}$ sulfate from $16 \mathrm{mM}$ thiosulfate after growth for $48 \mathrm{~h}$ at $65{ }^{\circ} \mathrm{C}$ with a concomitant decrease in $\mathrm{pH}$ from 7.7 to 5.3 and 5.0, respectively. The strains were also capable of sulfur oxidation in the presence of yeast extract, but less efficiently than with thiosulfate. Both produced $0.6 \mathrm{mM}$ sulfate when incubated with sulfur $\left(2 \mathrm{~g} \mathrm{l}^{-1}\right)$ at $65^{\circ} \mathrm{C}$ for $48 \mathrm{~h}$. Similar results were obtained for both 'T. kawarayensis' DSM 16200 and T. igniterrae DSM $12459^{\mathrm{T}}$ (Table 1). Previously, T. scotoductus IT-7254 has been shown to oxidize thiosulfate and elemental sulfur (Skirnisdottir et al., 2001). Furthermore, the growth of this strain in nutrient medium was enhanced by thiosulfate as shown here for strains PRI 2268 and PRI $3838^{\mathrm{T}}$.

Cellular fatty acids were extracted from bacteria grown in medium 166 at $65{ }^{\circ} \mathrm{C}$ according to the protocol of the MIDI system. Analysis by GC was controlled by the MIS software and the peaks were automatically integrated and identified by the Microbial Identification software package (Sasser, 1990). The predominant fatty acids of strain PRI $3838^{\mathrm{T}}$ were iso- $17: 0(26.2 \%)$, iso- $15: 0(23.7 \%)$, anteiso$15: 0(20.3 \%)$ and anteiso- $17: 0(15.2 \%)$. Other fatty acids detected were mainly $16: 0(5.5 \%)$, iso- $16: 0(4.7 \%)$, iso$14: 0(1.2 \%)$ and $17: 0(1.1 \%)$. The ratio of fatty acids anteiso-15:0 and anteiso-17:0 for strain PRI $3838^{\mathrm{T}}$ was relatively high compared with many other species of the genus Thermus (Chung et al., 2000). The predominant fatty acids of strain PRI $3838^{\mathrm{T}}$ were also detected in high ratios in the reference strain, ' $T$. kawarayensis'. This strain contained mainly iso-15:0 (32.8\%), iso-17:0 (25.5\%), anteiso-15:0 (13.4\%) and anteiso-17:0 (9.0\%). Analyses of polar lipids and respiratory quinones were carried out by the DSMZ (B. J. Tindall). Menaquinones MK8 (96\%) and MK7 $(2 \%)$ were detected in strain PRI $3838^{\mathrm{T}}$. Two major phospholipids (PL1 and PN) and one major glycolipid (GL5) were identified along with a minor phospholipid (PL2) and several minor glycolipids (GL1-GL4 and GL6).

The species status of strains PRI 2268 and PRI $3838^{\mathrm{T}}$ was demonstrated by a DNA-DNA hybridization value of $46.1 \%$ between strain PRI $3838^{\mathrm{T}}$ and 'T. kawarayensis' DSM 16200. DNA-DNA hybridization was performed by the DSMZ as described by De Ley et al. (1970) with the modifications of Huß et al. (1983). The G $+\mathrm{C}$ content of DNA was determined by the DSMZ according to Mesbah et al. (1989). DNA was purified as described by Cashion et al. (1977). The DNA G + C composition of strain PRI $3838^{\mathrm{T}}$ was determined as $69.0 \mathrm{~mol} \%$. This was similar to the value for ' $T$. kawarayensis', which was determined as $68.0 \mathrm{~mol} \%$ and to that of $T$. igniterrae (Chung et al., 2000). However, this value was higher than that obtained for other species of the genus Thermus (63-65 mol\% G + C) (da Costa et al., 2001).

The 16S rRNA genes of strains PRI $3838^{\mathrm{T}}$ and PRI 2268 were amplified using Dynazyme (Finzymes) and primers 
F9 (5'-GAGTTTGATCCTGGCTCAG-3') and R1544 (5'AGAAAGGAGGTGATCCA-3') (Skirnisdottir et al., 2000). Reactions were subjected to $5 \mathrm{~min}$ at $94{ }^{\circ} \mathrm{C}, 30$ cycles of $94{ }^{\circ} \mathrm{C}$ for $1 \mathrm{~min}, 52{ }^{\circ} \mathrm{C}$ for $1 \mathrm{~min}$ and $72{ }^{\circ} \mathrm{C}$ for $1.5 \mathrm{~min}$ and finally to $7 \mathrm{~min}$ at $72{ }^{\circ} \mathrm{C}$. Amplification products were purified using ExoSapIt (Amersham Biosciences) and their sequences determined using ABI 3730 DNA Analyzer and a BigDye Terminator Cycle Sequencing kit (Applied Biosystems). The primers F9 and R1544 were used for sequencing as well as R805 (5'-GACTACCCGGGTATCTAATCC- $\left.3^{\prime}\right), \quad$ F338 (5' -ACICCTACGGGIGGCAGCAG3'), R357 (5'-CTGCTGCCICCCGTAGG-3') and R1195 (5'-GACGTCITCCCCICCTTCCTC-3') (Skirnisdottir et al., 2000). The sequences were assembled and analysed using Sequencher version 4.8 (GeneCodes). They were aligned with those of other species of the genus Thermus (1442 bp) by using CLUSTAL_X software (Thompson et al., 1997). Evolutionary distance matrices were calculated using the Kimura two-parameter model (Kimura, 1980). A phylogenetic tree was constructed according to the neighbour-joining method of Saitou \& Nei (1987). The tree was displayed with NJPLOT (Perrière \& Gouy, 1996) and its topology was evaluated by a bootstrap analysis with 1000 trial replications. The $16 \mathrm{~S}$ rRNA gene sequences of strain PRI 2268 and PRI $3838^{\mathrm{T}}$ were found to be $99.7 \%$ similar and $98.8 \%$ similar to the previously identified sequence SRI-248 (Skirnisdottir et al., 2000). The phylogenetic tree (Fig. 1) revealed that ' $T$. kawarayensis' KW11 was the closest relative of the new isolates $(96.5 \%$ sequence similarity). Gene sequence similarity values of $96.1 \%$ and $95.9 \%$ were found to T. aquaticus $\mathrm{YT}-1^{\mathrm{T}}$ and $T$. igniterrae $\mathrm{RF}-4^{\mathrm{T}}$, respectively.

On the basis of physiological differences between the novel strains and related organisms (Table 1) and on 16S rRNA gene sequence similarity and DNA-DNA relatedness values of $96.5 \%$ and $46.1 \%$, respectively, between strain PRI $3838^{\mathrm{T}}$ and the closest relative ' $T$. kawarayensis', a novel species of the genus Thermus, namely Thermus islandicus sp. nov., is proposed to accommodate strains PRI 2268 and PRI $3838^{\mathrm{T}}\left(=\right.$ DSM $21543^{\mathrm{T}}=$ ATCC BAA- $\left.1677^{\mathrm{T}}\right)$.

\section{Description of Thermus islandicus sp. nov.}

Thermus islandicus (is.lan'di.cus. N.L. masc. adj. islandicus from Iceland, pertaining to the location of its first isolation).

Cells are non-spore-forming, non-motile rods measuring $0.3 \mu \mathrm{m}$ in width and $1.5-2.5 \mu \mathrm{m}$ in length. Cells stain Gram-negative and contain a thick envelope and a typical Gram-negative cell-wall profile. Aerobic, oxidase-positive, catalase-negative and does not reduce nitrate. Colonies are light yellow, slightly irregular, umbonate, undulate and 1$1.5 \mathrm{~mm}$ after 4 days at $65{ }^{\circ} \mathrm{C}$ on medium 166. Grows between 45 and $79{ }^{\circ} \mathrm{C}$ (optimum, $65{ }^{\circ} \mathrm{C}$ ) and from pH 5.510.5 (optimum, pH 6.0-7.0). Grows well in medium 166 and R2A. Pyruvate, glycerol and starch support growth of the type strain at $60{ }^{\circ} \mathrm{C}$ when supplemented with yeast extract. Weak growth is exhibited on cellobiose, lactose and inositol. Does not utilize arabinose, fructose, galactose, glucose, mannose, melibiose, raffinose, rhamnose, ribose, sucrose, trehalose, xylose, ribitol, mannitol, sorbitol, citrate, malate, L-arginine, L-glutamine, L-serine or Casamino acids. Capable of mixotrophic growth with sulfur-oxidation in medium 166 supplemented with thiosulfate and in minimal medium supplemented with thiosulfate and yeast extract. Susceptible to ampicillin, gentamicin, novobiocin, kanamycin, penicillin and streptomycin. Resistant to nalidixic acid, polymyxin B and rifampicin. The predominant menaquinone is MK8. The

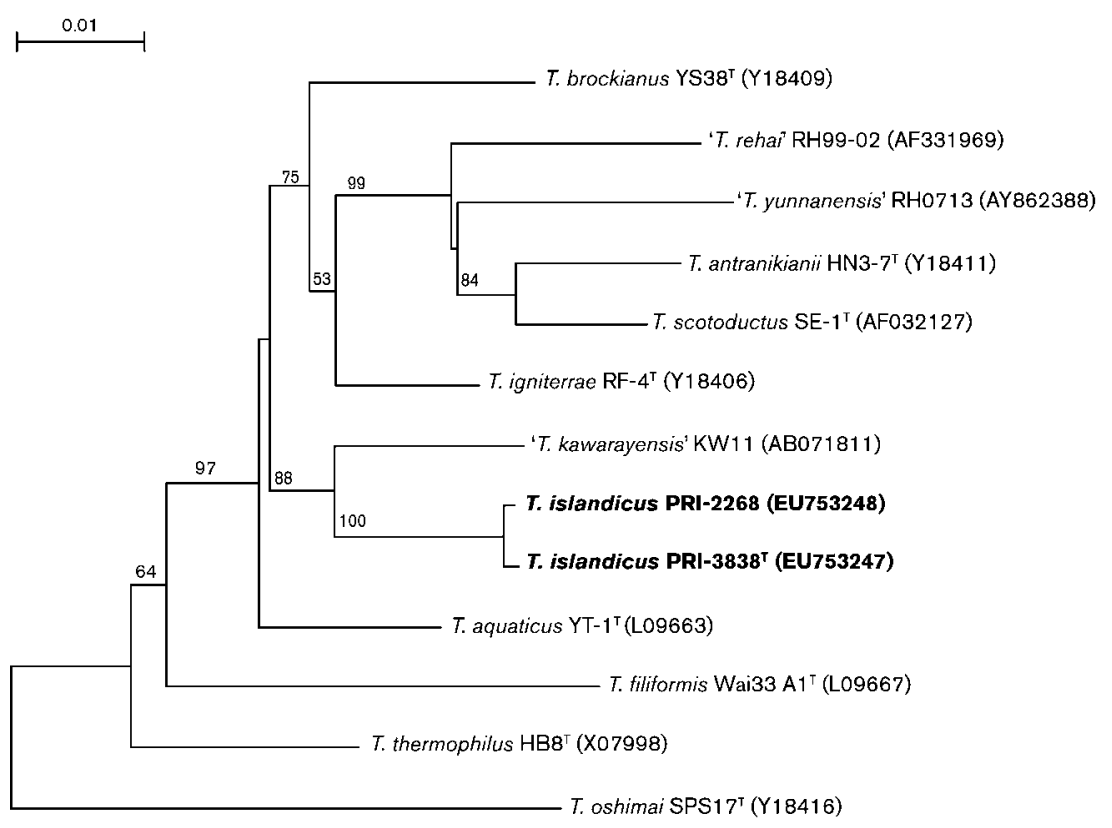

Fig. 1. Neighbour-joining phylogenetic tree derived from analysis of 16S rRNA gene sequences (Kimura's two-parameter method) showing the position of strains PRI 2268 and PRI $3838^{\top}$ among other members of the genus Thermus. GenBank accession numbers are given in parentheses. Bootstrap values (1000 replications) are shown as percentages at each node only if they are $\geqslant 50 \%$. Bar, 0.01 substitutions per nucleotide position. 
major fatty acids are iso-17:0, iso $15: 0$, anteiso $15: 0$ and anteiso $17: 0$.

The type strain, PRI $3838^{\mathrm{T}}\left(=\right.$ DSM $21543^{\mathrm{T}}=$ ATCC BAA$\left.1677^{\mathrm{T}}\right)$, was isolated from a hot spring in the Torfajokull geothermal area in Iceland. Strain PRI 2268 is a reference strain. The DNA G+C content of the type strain is $69 \mathrm{~mol} \%$.

\section{Acknowledgements}

This work was supported by the Research Fund from the Icelandic Centre for Research and by the National Energy Authority of Iceland. We thank Andri Stefansson (University of Iceland) for the hydrogen sulfide measurements. We also thank Sasan Rabieh for performing the ICP-MS, and Jon Matthiasson and Ægir Thor Thorsson for assistance during scanning electron microscopy and sampling, respectively.

\section{References}

Brock, T. D. \& Freeze, H. (1969). Thermus aquaticus gen. n. and sp. n., a non-sporulating extreme thermophile. J Bacteriol 98, 289-297.

Cashion, P., Holder-Franklin, M. A., McCully, J. \& Franklin, M. (1977). A rapid method for base ratio determination of bacterial DNA. Anal Biochem 81, 461-466.

Chung, A. P., Rainey, F. A., Valente, M., Nobre, M. F. \& da Costa, M. S. (2000). Thermus igniterrae sp. nov. and Thermus antranikianii sp. nov., two new species from Iceland. Int J Syst Evol Microbiol 50, 209217.

da Costa, M. S., Nobre, M. F. \& Rainey, F. A. (2001). Genus I. In Bergey's Manual of Systematic Bacteriology, pp. 404-414. Edited by G. Garrity, D. R. Boone \& R. W. Castenholz. Vol. 1. New York: Springer. da Costa, M. S., Rainey, F. A. \& Nobre, M. F. (2006). The genus Thermus and relatives. In The Prokaryotes. A Handbook on the Biology of Bacteria, 3rd edn, vol. 7, pp. 797-812. Edited by M. Dworkin, S. Falkow, E. Rosenberg, K. H. Schleifer \& E. Stackebrandt. New York: Springer.

De Ley, J., Cattoir, H. \& Reynaerts, A. (1970). The quantitative measurement of DNA hybridization from renaturation rates. Eur $J$ Biochem 12, 133-142.

Degryse, E., Glansdorff, N. \& Piérard, A. (1978). A comparative analysis of extreme thermophilic bacteria belonging to the genus Thermus. Arch Microbiol 117, 189-196.

Eaton, A. D., Clesceri, L. S., Rice, E. W. \& Greenberg, A. E. (2005). Standard Methods for the Examination of Water and Wastewater. Washington DC: American Public Health Association.

Gihring, T. M. \& Banfield, J. F. (2001). Arsenite oxidation and arsenate respiration by a new Thermus isolate. FEMS Microbiol Lett 204, 335340.

Hjorleifsdottir, S., Skirnisdottir, S., Hreggvidsson, G. O., Holst, O. \& Kristjansson, J. K. (2001). Species composition of cultivated and noncultivated bacteria from short filaments in an Icelandic hot spring at $88^{\circ} \mathrm{C}$. Microb Ecol 42, 117-125.

Hobel, C. F. V., Marteinsson, V. T., Hauksdottir, S., Fridjonsson, O. H., Skirnisdottir, S., Hreggvidsson, G. O. \& Kristjansson, J. K. (2004). Use of low nutrient enrichments to access novel amylase genes in silent diversity of thermophiles. World J Microbiol Biotechnol 20, 801-809.
Hreggvidsson, G. O., Skirnisdottir, S., Smit, B., Hjorleifsdottir, S., Marteinsson, V. T., Petursdottir, S. \& Kristjansson, J. K. (2006). Polyphasic analysis of Thermus isolates from geothermal areas in Iceland. Extremophiles 10, 563-575.

Hudson, J. A., Morgan, H. W. \& Daniel, R. M. (1987). Thermus filiformis sp. nov., a filamentous caldoactive bacterium. Int J Syst Bacteriol 37, 431-436.

Huß, V. A. R., Festl, H. \& Schleifer, K. H. (1983). Studies on the spectrophotometric determination of DNA hybridization from renaturation rates. Syst Appl Microbiol 4, 184-192.

Kieft, T. L., Fredrickson, J. K., Onstott, T. C., Gorby, Y. A., Kostandarither, H. M., Bailey, T. J., Kennedy, D. W., Li, S. W., Plymale, A. E. \& other authors (1999). Dissimilatory reduction of $\mathrm{Fe}(\mathrm{III})$ and other electron acceptors by a Thermus isolate. Appl Environ Microbiol 65, 1214-1221.

Kimura, M. (1980). A simple method for estimating evolutionary rates of base substitutions through comparative studies of nucleotide sequences. J Mol Evol 16, 111-120.

Kristjansson, J. K., Hjorleifsdottir, S., Marteinsson, V. \& Alfredsson, G. A. (1994). Thermus scotoductus, sp. nov., a pigment-producing thermophilic bacterium from hot tap water in Iceland and including Thermus sp. X-1. Syst Appl Microbiol 17, 44-50.

Kurosawa, N., Itoh, Y. H. \& Itoh, T. (2005). Thermus kawarayensis sp. nov., a new member of the genus Thermus, isolated from Japanese hot springs. Extremophiles 9, 81-84.

Mesbah, M., Premachandran, U. \& Whitman, W. (1989). Precise measurement of the $\mathrm{G}+\mathrm{C}$ content of deoxyribonucleic acid by high performance liquid chromatography. Int J Syst Bacteriol 39, 159-167.

Perrière, G. \& Gouy, M. (1996). WWW-Query: An on-line retrieval system for biological sequence banks. Biochimie 78, 364-369.

Saitou, N. \& Nei, M. (1987). The neighbor-joining method: a new method for reconstructing phylogenetic trees. Mol Biol Evol 4, 406425.

Sasser, M. (1990). Identification of Bacteria by Gas Chromatography of Cellular Fatty Acids. MIDI Technical Note 101. Newark, DE: MIDI Inc.

Skirnisdottir, S., Hreggvidsson, G. O., Hjorleifsdottir, S., Marteinsson, V. T., Petursdottir, S., Holst, O. \& Kristjansson, J. K. (2000). Influence of sulfide and temperature on species composition and community structure of hot spring microbial mats. Appl Environ Microbiol 66, 2835-2841.

Skirnisdottir, S., Hreggvidsson, G. O., Holst, O. \& Kristjansson, J. K. (2001). Isolation and characterization of a mixotrophic sulfuroxidizing Thermus scotoductus. Extremophiles 5, 45-51.

Tabatabai, M. A. (1974). A rapid method for determination of sulfate in water samples. Environ Lett 7, 237-243.

Thompson, J. D., Gibson, T. J., Plewniak, F., Jeanmougin, F. \& Higgins, D. G. (1997). The CLUSTAL_X window interface: flexible strategies for multiple sequence alignment aided by quality analysis tools. Nucleic Acids Res 25, 4876-4882.

Williams, R. A. D., Smith, K. E., Welch, S. G., Micallef, J. \& Sharp, R. J. (1995). DNA relatedness of Thermus strains, description of Thermus brockianus sp. nov., and proposal to reestablish Thermus thermophilus (Oshima and Imahori). Int J Syst Bacteriol 45, 495-499.

Williams, R. A. D., Smith, K. E., Welch, S. G. \& Micallef, J. (1996). Thermus oshimai sp. nov., isolated from hot springs in Portugal, Iceland, and the Azores and comment on the concept of a limited geographical distribution of Thermus species. Int J Syst Bacteriol 46, 403-408. 